\title{
ARAH PENGEMBANGAN KAJIAN EKONOMI ISLAM BERBASIS KESATUAN ILMU PENGETAHUAN DI IAIN WALISONGO
}

\author{
Ali Murtadho ${ }^{1}$
}

\begin{abstract}
Abstrak
Nomenklatur ekonomi Islam atau ekonomi syari'ah sepintas memperlihatkan adanya dikhotomi antara ilmu ekonomi Islam/Syari'ah dengan ilmu ekonomi umum/konvensional. Karakteristik ekonomi Islam sudah terelaborasi dalam berbagai kajian kontemporer dengan kekhasan tersendiri. Di sisi lain, paradigma wahdat al"ulum/unity of science sebagai basis pengembangan ilmu dalam visi LAIN Walisongo berarti menafikan berbagai dikhotomi antara ilmu "Islam" dengan ilmu "non Islam"/umum/konvensional. Paradigma ini menuntut elaborasi lebih lanjut dalam konteks pengembangan ilmu ekonomi Islam di LAIN walisongo. Melalui strategi spiritualisasi ilmu ekonomi konvensional, humanisasi ilmu syariah dan revitalisasi budaya/praktike ekonomi lokal, arah pengembangan ekonomi Islam dapat diformulasikan dalam implementasi kesatuan ilmu pengetahuan.
\end{abstract}

Keyword : Ilmu Ekonomi Islam, Kesatuan ilmu pengetahuan

\section{Pendahuluan}

Dengan visi terbarunya, ${ }^{2}$ Institut Agama Islam Negeri (IAIN) Walisongo berkomitmen untuk menjadikan unity of science/wabdat al'ulum/kesatuan ilmu pengetahuan sebagai paradigma pengembangan IAIN Walisongo menjadi perguruan tinggi Islam riset terdepan. Peletakan dasar unity of sciences ini ditujukan untuk memberikan nilai guna bagi kemanusiaan dan peradaban. Kesatuan ilmu pengetahuan ini bermakna menafikan adanya berbagai dikotomi ilmu, seperti dikotomi antara ilmu umum dengan ilmu

${ }^{1}$ Dosen Fakultas Ekonomi dan Bisnis Islam IAIN Walisongo Semarang

${ }^{2}$ Visi terbaru IAIN Walisongo adalah "Perguruan Tinggi Islam riset terdepan berbasis pada kesatuan ilmu pengetahuan untuk kemanusiaan dan peradaban." Lihat: Keputusan Rektor IAIN Walisongo Nomor 10 tahun 2014 tentang Visi, Misi dan Tujuan Institut Agama Islam Negeri Walisongo, tertanggal 12 Pebruari 2014. 
Arah Pengembangan Kajian Ekonomi Islam

agama, dikotomi antara yang profan dengan yang sakral, akankah menafikan pula dikotomi antara yang konvensional dengan yang syari'ah. Makna kesatuan ilmu pengetahuan dipertegas secara aksiologis "untuk kemanusiaan dan beradaban" yang berarti mempertegas misi Islam rahmatan lil-alamin, menebarkan kesejahteraan bagi semesta alam yang menolak pemihakan pada golongan atau aliran tertentu.

Dengan disahkannya visi tersebut dalam Keputusan Rektor IAIN Walisongo Nomor 10 tahun 2014, maka seluruh bangunan keilmuan di IAIN yang dikembangkan oleh masing-masing program studi di IAIN Walisongo harus selaras dan menyokong terwujudnya visi tersebut. Artikel ini secara khusus menelaah bagaimana mengejawantahkan visi berbasis kesatuan ilmu pengetahuan tersebut dalam mengembangkan kajian ekonomi Islam yang menjadi amanat akademis Fakultas terbaru IAIN Walisongo yakni Fakultas Ekonomi dan Bisnis Islam. Mengingat nomenklatur ilmu ekonomi Islam sepintas masih menyiratkan adanya dikotomi keilmuan yang bisa saja dipandang masih mengandung unsur formalisme sektarian yang kurang universal.

\section{Sekilas tentang Unity of Science}

Munculnya konsep, gagasan atau gerakan penyatuan ilmu pengetahuan/unity of sience atau integrasi keilmuan tentu dilatarbelakangi kondisi tertentu yang menimpa dunia ilmu pengetahuan. Oleh karena itu pemaknaan konsep unity of science sangat tergantung pada apa yang melatarbelakangi kemunculannya. Bisa saja unity of science muncul karena terjadinya pemisahan, pembedaan atau dikotomi keilmuan, atau karena adanya berbagai pandangan yang berbeda-beda tentang hakekat masing-masing ilmu pengetahuan yang mengakibatkan terdistorsinya ilmu pengetahuan sehingga tidak mampu memberikan manfaat maksimal bagi kehidupan.

Unity of science dimaknai sebagai integrasi keilmuan karena adanya dikotomi ilmu, yang telah melewati sejarah dan proses tersendiri. Dalam pandangan Mulyadhi Kartanegara, dikotomi ilmu antara ilmu agama dengan ilmu non agama telah terjadi di dunia Islam sejak ribuan tahun silam.tetapi 
dikotomi ini tidak menimbulkan masalah dalam pendidikan Islam, sampai diperkenalkannya system pendidikan sekuler barat ke dunia Islam melalui imperialisme. Berbeda dengan dikotomi diversifikasi ilmu yang dikenal dalam khazanah klasik Islam yang masih mengakui validitas dan status ilmiah masingmasing ilmu, dikotomi ilmu yang dibawa Barat dimaksudkan untuh memandang rendah ilmu-ilmu ke-Islaman. Ilmuan modern barat memandang ilmu agama tidak bias dikategorikan ilmiah karena tidak memenuhi persyaratan keilmiahan ilmu yakni harus empiris. Ilmu-ilmu sekuler positivistic yang diperkenalkan Barat ke dunia Islam lewat imperialism memperuncing dikotomi antara ilmu-ilmu agama yang dikembangkan pesantren/lembaga pendidikan keagamaan dengan ilmu umum yang diajarkan di sekolah yang didirikan penjajah. ${ }^{3}$

Realitas ini memicu bangkitnya para pemikir Muslim mengcounter dikotomi tersebut. Antara lain, sebagaimana dikutip Mulyadhi Kartanegara, Sayyed Hussein Nasr menegaskan bahwa ilmuwan Muslim mempelajari fenomena alam (yang dianggap ilmu sekuler bukan ilmu agama) bukan sekedar memenuhi rasa ingin tahu semata tetapi utuk mengamati dari dekat jejak-jejak Ilahi. Fenomena alam bukan realitas yang mandiri tetapi merupakan signs/ayat Allah yang membimbing kearah religiusitas keyakinan dan perilaku. ${ }^{4}$ Di dunia Muslim timbul kesadaran bahwa pemisahan antara ilmu dan agama berakibat pada rendahnya kualitas pendidikan dan mundurnya dunia Islam pada umumnya. ${ }^{5}$ Muncul upaya-upaya mengintegrasikan keduanya dengan berbagai varian istilah. Ada yang memakai istilah islamisasi lmu pengetahuan, ada yang lebih suka dengan istilah pengilmuan Islam sebagaimana yang dipakai Kuntowijoyo. ${ }^{6}$

Menurut Sholihan, pemikiran tentang integrasi sains dan agama di dunia Islam dapat dikelompokkan ke dalam dua arus utama. Pertama, para pemikir yang berusaha melakukan integrasi antara sains dengan Islam dengan cara memberikan visi Islam ke dalam sains modern Barat. Konsep ini disebut

\footnotetext{
3 Mulyadhi Kartanegara, Integrasi Ilmu: Sebuah Rekonstruksi Holistik, Bandung: Penerbit Arasy PT Mizan Pustaka, 2005, hlm. 19-20.

${ }^{4}$ Ibid., hlm. 21.

${ }^{5}$ M. Hasan Bisyri, Mengakhiri Dikhotomi Ilmu dalam Dunia Pendidikan, Forum Tarbiyah, Vol.7 No.9 Desember 2009, hlm. 182.

${ }^{6}$ Ibid., hlm. 190.
} 
Arah Pengembangan Kajian Ekonomi Islam

dengan gagasan Islamisasi Sains, sebagaimana dikembangkan oleh tokoh-tokoh seperti Seyyed Hossein Nasr, Mohammad Naquib al-Atas, dan Ismail Raji alFaruqi. Kedua, para pemikir yang berusaha melakukan integrasi antara sains dengan Islam dengan cara menggunakan sains, terutama sains sosial dan humaniora yang muncul pada abad ke-19 dan sesudahnya, sebagai pendekatan dalam mengembangkan ilmu-ilmu keislaman. Kecenderungan semacam ini ini dilakukan oleh para tokoh seperti Hassan Hanafi, Fazlur Rahman, Arkoun, dan Mohammed Abid al-Jabiri. ${ }^{7}$

\section{Permasalahan}

Terlepas dari fenomena dikotomi ilmu di dunia Islam, di dunia ilmu pengetahuan modern secara umum juga muncul kecenderungan penyatuan ilmu pengetahuan dengan makna tersendiri. Misalnya kecenderungan Unity of science dimaknai sebagai kesatuan pluralitas ilmu pengetahuan dalam satu value yang dipegangi bersama. Ketika dirasa telah terjadi pemisahan antara ilmu dengan etika, maka kecenderungan kesatuan pluralitas ilmu pengetahuan bermakna kecenderungan etis. Sebagai wujud tanggung jawab etis, pendukung ilmu pengetahuan jenis apapun diharapkan tetap mengarah pada orientasi yang sama, yaitu bagi terwujudnya "kebahagian hidup dan kehidupan seluruh umat manusia dan masyarakatnya di dalam ekosistem alam yang utuh". ${ }^{8}$

\section{Pembahasan}

\section{Unity of Sciences sebagai Paradigma Institusi IAIN Walisongo}

Lantas apa yang dimaksudkan dengan kesatuan ilmu pengetahuan yang ditegaskan dalam visi terbaru IAIN Walisongo ? Dalam seminar yang diselenggarakan IAIN Walisongo bertema "Sosialisasi Strategi Pengembangan Tri Dharma IAIN Walisongo Berbasis Paradigma Unity of Sciences", Dr.

\footnotetext{
7 Sholihan, Epistemologi Pengembangan Ilmu dengan Paradigma Unity of Sciences/Wahdah Al-'Ulum (Ilmu Dakwah sebagai Model), Disampaikan dalam Studium General Fakultas Dakwah dan Komunikasi IAIN Walisongo, Semarang, 3 Maret 2014.

${ }^{8}$ Muh. Amri Nur Kamal, Filasafat Ilmu Pengetahuan, http://paradigmascience. blogspot.com / 2011/05/filsafat-ilmu-pengetahuan_15.html, diakses 25 April 2014.
} 
Muhaya menegaskan pentingnya memahami kesatuan ilmu pengetahuan (unity of sciences) atau juga disebut wahdah al ulum. Menurutnya, dari perspektif historis Islam sangat responsif terhadap ilmu pengetahuan baik umum maupun agama sehingga ilmu-ilmu ke-Islaman menjadi humanis. Dapat dilihat misalnya ajaran orang-orang terdahulu tentang 'alimun bi al 'ulum al akhirah, faqihan bi maslahah al khalqi fi al dunya muridan bi fiqhi wajhillah. Tetapi sekarang di kalangan pendidikan terjadi pemahaman yang parsial. ${ }^{9}$

Dr. H. Imam Taufiq, M.Ag, ketua LPM IAIN Walisongo, menulis di Harian Suara Merdeka mengenai penegasan IAIN Walisongo terhadap wahdat al-ulum (unity of sciences) sebagai paradigma institusi. Menurutnya, ilmu sejatinya adalah kesatuan tak terpisahkan yang berasal dari Sang Pencipta, baik berupa kalam-Nya yang sakral maupun terbentang dalam realitas kenyataan. Ilmu berwatak progresif, aktif, dan tidak statis. Sedangkan wahyu dipandang sebagai fondasi perekat penyatuan ilmu pengetahuan. Ilmu pengetahuan selalu berproses dan berdialog $\backslash \backslash \backslash=$ pp dengan menuju tujuan tunggal, yaitu Sang Pencipta Yang Maha Tahu. Yang dihasilkan dari model kesatuan ilmu ini adalah sosok komprehensif, mampu mengomunikasikan berbagai bidang ilmu dengan realitas. ${ }^{10}$

Sedangkan menurut Dr. H. Sholihan, M.Ag, ketua LPPM IAIN Walisongo, paradigma unity of science yang ditetapkan oleh IAIN Walisongo, adalah merupakan upaya untuk melakukan integrasi, tidak hanya antara agama dan sains, melainkan juga pada integrasi antara gagasan/ gerakan humanisasi Ilmu-ilmu Keislaman dan Islamisasi Ilmu. Menurut Sholihan, paradigma Unity of Sciences/ Wahdah al-'Ulum IAIN Walisongo ini bukan Tauhid al-'Ulum, bukan Integrasi Ilmu, bukan Unity of Sciences versi gagasan Lingkaran Wina, juga bukan Unity of Sciences sebagaimana gagasan Jean Piaget (1950) yang menyatakan bahwa:tesis unity of science ada dalam prinsip bahwa semua ilmu adalah bagian dari satu organisasi pengetahuan yang terdiri dari berbagai tingkatan: ilmu fisika yang paling dasar, kimia level diatasnya, biologi di atas kiia, sosiologi di atas biologi an seterusnya. ${ }^{11}$

9 "IAIN Walisongo Matangkan Paradigma Unity of Sciences", http://www.suaramerdeka.com /, 08 Desember 2013.

${ }^{10}$ Imam Taufiq, "Komitmen Kebangsaan IAIN”, Suara Merdeka, 7 April 2014.

${ }^{11}$ Sholihan, Loc.Cit 
Arah Pengembangan Kajian Ekonomi Islam

Sholihan menegaskan unity of science merupakan "Suatu keyakinan bahwa Ilmu itu satu. Tidak ada dikotomi antara ilmu yang datang dari Tuhan maupun dari manusia." Paradigma ini memakai pendekatan Teoantroposentris didasarkan pada pandangan Islam tentang Ilmu, baik dalam dimensi ontologis, epistemologis, maupun aksiologisnya. Dalam dimensi ontologis whatness) ilmu adalah keseluruhan realitas, baik yang metafisik maupun yang fisik; baik teks Qur'aniyyah maupun teks Kauniyyah. Implikasinya adalah tidak adanya dikotomi objek ilmu antara yang metafisik dan yang fisik, dan juga tidak adanya dikotomi jenis ilmu antara ilmu mengenai teks Qur'aniyyah dan ilmu mengenai teks Kauniyyah. Dalam dimensi dimensi epistemologis (howness) ilmu, yang mengakui dua sumber ilmu, yakni dari Tuhan dan dari manusia sekaligus, baik melalui potensi indera, akal, maupun intuisinya. Implikasi dari pandangan demikian adalah tidak adanya dikotomi metodologis dalam memahami realitas. Ada pluralitas metodologis dalam mendapatkan ilmu, sejalan dengan adanya pluralitas realitas yang menjadi objek ilmu. Sedangkan dalam dimensi aksiologis (whyness) ilmu, yang memiliki dua orientasi nilai, yakni nilai ketuhanan dan nilai kemanusiaan sekaligus. Pengembangan ilmu secara aksiologis menolak pandangan yang dikotomis antara orientasi pada nilai ketuhanan atau nilai kemanusiaan semata, lebih-lebih pandangan yang menyatakan bahwa ilmu bebas nilai. ${ }^{12}$

Lebih lanjut Sholihan menjelaskan bahwa meskipun ilmu itu tidak dikotomis, namun realitas sekarang ilmu bersifat dikotomis. Oleh karena itu diperlukan strategi humanisasi ilmu-ilmu keislaman, spiritualisasi ilmu-ilmu modern dan revitalisasi local wisdom. Humanisasi Ilmu-ilmu keislaman berarti merekonstruksi ilmu-ilmu keislaman agar semakin menyentuh dan memberi solusi bagi persoalan nyata kehidupan manusia Indonesia. Strategi humanisasi ilmu-ilmu keislaman mencakup semua upaya untuk memadukan nilai universal Islam dengan ilmu pengetahuan modern guna peningkatan kualitas hidup dan peradaban manusia. Yang dimaksud dengan spiritualisasi ilmu-ilmu modern adalah memberi pijakan nilai-nilai ketuhanan (ilahiyah) dan etika pada ilmuilmu modern untuk memastikan bahwa pada dasarnya semua ilmu berorientasi pada peningkatan kualitas/keberlangsungan hidup manusia dan alam serta bukan penistaan/perusakan keduanya. Strategi spiritualisasi ilmu-ilmu modern

12 Ibid. 
mencakup segala upaya membangun ilmu pengetahuan baru yang didasarkan pada kesadaran kesatuan ilmu yang kesemuanya bersumber dari ayat-ayat Allah baik yang diperoleh melalui para nabi, eksplorasi akal, maupun ekplorasi alam. Sedangkan revitalisasi local wisdom berarti penguatan kembali ajaran-ajaran luhur bangsa. Strategi revitalisasi local wisdom meliputi semua usaha untuk tetap setia pada ajaran luhur budaya local dan pengembangannya guna penguatan karakter bangsa. ${ }^{13}$

\section{Ekonomi Islam Vs Ekonomi Konvensional: Dikhotomi Keilmuan ?}

Sepintas dengan istilah ilmu ekonomi Islam seperti tersirat adanya pembedaannya dengan ilmu ekonomi yang tidak Islam. Seakan ada dikotomi antara ekonomi umum/kovensioanl dengan ekonomi Islam, begitu pula ilmu turunannya ada ilmu akuntansi Islam di samping ilmu akuntansi, ada manajemen Islam di samping ilmu manajemen. Apa sebenarnya yang dimksud dengan ilmu ekonomi Islam, yang kini menyemarakkan dunia ilmu ekonomi konemporer. Pada dasarnya ekonomi merupakan bagian dari ilmu sosial ${ }^{14}$ yang berbicara masalah penghidupan manusia dengan beragam topiknya. Ekonomi pada umumnya didefinisikan sebagai kajian tentang perilaku manusia dalam hubungannya dengan pemanfatan sumber-sumber produktif yang langka untuk memproduksi barang dan jasa serta mendistribusikannya untuk dikonsumsi. ${ }^{15}$ Sedangkan ilmu ekonomi Islam didefinisikan sebagai suatu cabang ilmu pengetahuan yang membantu merealisasikan kesejahteraan manusia melalui alokasi dan distribusi sumber-sumber daya langka yang sesuai dengan maqashid al-syari'ah tanpa mengekang kebebasan individu. ${ }^{16}$

Mengenai awal munculnya ilmu ekonomi konvensional dan ilmu ekonomi Islam, ada saling klaim antara keduanya mana yang lebih dahulu

\footnotetext{
${ }^{13}$ Ibid.

${ }^{14}$ Troy J. Cauley, seorang ekonom, membagi ilmu pengetahuan menjadi tiga: ilmu fisika, ilmu biologi dan ilmu sosial, di mana ekonomi termasuk di dalamnya. Lihat : Troy J. Cauley, Economics: Principles and Institutions (Pennsylvania: The Haddon Craftsmen, Inc., 1969), 4-5, 11.

15 Monzer Kahf, The Islamic Economy, Analytical Economy of The Function of The Islamic Economic System, terj. Machnun Husein, "Ekonomi Islam (Telaah Analitik terhadap Fungsi Sistem Ekonomi Islam)", Yogyakarta: Pustaka Pelajar, 1995, hlm. 2.

16 Muhammad, Prinsip-prinsip ekonomi Islam, Yogyakarta: Graha Ilmu, 2007, hlm. 1-14, dalam http://renoparay.blogspot.com/2013/, diakses 26 April 2014.
} 
Arah Pengembangan Kajian Ekonomi Islam

muncul. Buku-buku sejarah pemikiran ekonomi yang ditulis ekonom Barat kebanyakan memulai era pemikiran ekonomi pada abad ke-18 yang ditandai masa pencerahan di dunia Barat, dan dengan munculnya karya Adam Smith (1776) dengan karyanya yang berjudul An Inquiry into the Nature and Causes of the Wealth of Nations. Bahkan diklaim bahwa sepanjang ribuan tahun sejarah manusia sebelum 1776 tidak muncul karya besar tentang ekonomi. ${ }^{17}$ Sementara dalam khazanah kepustakaan Islam, jauh sebelum itu sudah muncul banyak ahli yang berbicara masalah ekonomi, antara lain : Abu Yusuf (798 M) berbicara tentang kebijakan ekonomi dalam bukunya Al-Kharraj, Abu Ubaid (838 M) menerangkan tentang keuangan public dalam Islam dengan mengintrodusir masalah hak pemerintah atas warga dan hak warga atas pemerintah dalam karyanya Al-Amwal. Demikian juga Al-Ghazali (1111 M), Ibn Taimiyah (1328 M), Ibn Khaldun (1404) dan masih banyak lagi yang berbicara masalah keuangan, ekonomi maupun kebijakan pemerintah di bidang ekonomi. ${ }^{18}$

Hanya mereka tidak tercover oleh ekonom Barat karena masa-masa para ilmuwan muslim itu adalah masa kegelapan untuk dunia Barat. Terlepas dari saling klaim mana yang lebih dahulu muncul, namun secara obyektif diakui bahwa antara keduanya ada saling mempengaruhi. Kemunculan ekonomi konvensional tidak terlepas dari interaksi dengan dunia Islam yang telah melahirkan khazanah tulisan-tulisan klasik yang berbicara tentang ekonomi. Demikian juga maraknya ekonomi Islam belakangan ini juga tidak terlepas dari sumbangan barat terutama dalam hal metodologi dan analisisnya. Para ilmuwan ekonomi Islam kontemporer sendiri disamping menegaskan bahwa ilmu ekonomi konvensional tidak terlepas dari pengaruh pemikir muslim seperti Ibn Khaldun dan yang lainnya, sebaliknya mereka juga mengakui bahwa wacana ekonomi Islam yang marak pada paruh kedua abad

17 Overton H. Taylor, A History of Economic Thought, New York : McGraw-Hill Book Company, Inc., 1960, hlm. 1. Lihat pula : Mark Skousen, The Making of Modern Economics The Lives and Ideas of the Great Thinkers, terj. Tri Wibowo Budi Santoso, "Sang Maestro Teori-teori Ekonomi Modern, Sejarah Pemikiran Ekonomi”, Jakarta : Prenada Media, 2005, hlm. 15-16.

${ }^{18}$ Zamruddin Hasid, "Reconstruction on Economic's Theory and Its Application : The Role of Islamic Bank", dalam : International Journal Ibya 'Ulum al-Din, Semarang : IAIN Walisongo, vol.7, no.1, Juli 2005, hlm. 38-40. 
ke-20 juga mendapat pengaruh yang nyata dari pemikiran ekonomi konvensional. ${ }^{19}$

1. Ada beberapa pandangan mengenai hakikat ekonomi Islam yang sekarang lagi marak dikaji: Ekonomi Islam adalah doktrin, bukan ilmu. Pandangan ini dikemukakan oleh M. Baqir Ash Shadr. Ia mengingatkan perlunya dibedakan antara doktrin dan ilmu pengetahuan.Doktrin ekonomi dalam sebuah masyarakat pada dasarnya menunjukkan cara atau metode yang dipilih dan diikuti masyarakat tersebut dalam kehidupan ekonominya serta dalam memecahkan setiap problem praktis yang dihadapinya. Sedangkan Ilmu ekonomi adalah ilmu yang berhubungan denga penjelasan terperinci perihal kehidupan ekonomi, peristiwa-peristiwanya, gejala-gejala (fenomena-fenomena) lahiriahny, serta hubungan antara peristiwaperistiwa dan fenomena-fenomena tersebut dengan sebab-sebab dan faktor umum yang mempengaruhinya. Ia menegaskan bahwa ekonomi Islam adalah sebuah doktrin dan bukan merupakan suatu ilmu pengetahuan. Ekonomi Islam adalah cara yang direkomendasikan Islam dalam mengejar kehidupan ekonomi, bukan merupakan suatu penafsiran atau penjelasan fenomena atau peristiwa-peristiwa yang terjadi dalam kehidupan ekonomi dan hukum-hukum yang berlaku di dalamnya. Sebagai doktrin, ekonomi Islam berisikan setiap aturan dasar dalam kehidupan ekonomi yang berhubungan dengan ideologi ((keadilan social). Semenara ilmu ekonomi berisikan setiap teori yang menjelaskan realitas kehidupan ekonomi, terpisah dari ideology awal atau cita-cita keadilan. ${ }^{20}$

2. Ilmu Ekonomi Islam itu seperti Ilmu Ekonomi konvensional namun memiliki tujuan tersendiri yakni merealisasikan kesejahteraan manusia sebgai realisasi dari maqasid syari'ah. Ilmu ekonomi Islam merupakan cabang ilmu pengetahuan yang unik dikarenakan menghubungkan antara nilai-nilai ketuhanan (ilahiyah) yang seharusnya terjadi dengan realitas apa adanya. Hal tersebut menjadikan ilmu ini sulit diterima dalam pandangan

${ }^{19}$ Lihat : Rifa'at Al-'Audhi, "Murtakazat li Tadris al-Iqtishad al-Islami" dalam : Jad al-Haqq 'Ali Jad al-Haqq, et.al, Abhats Nadwah Isham al-Fikr al-Islami fi al-Iqtishad al-Mu'ashir, Herndon : alMa'had al-'Alami li al-Fikr al-Islami, 1988, hlm. 52-53.

${ }^{20}$ M. Baqir Ash Shadr, Ringkasan Iqtishaduna "Ekonomi Kita” Maz̧hab \& Doktrin Ekonomi Islam, Yogyakarta: RusyanFikr Institute, 2012, hlm. 41-46. 
Arah Pengembangan Kajian Ekonomi Islam

ilmiah Barat yang menganggap bahwa suatu ilmu harus dapat menjelaskan realitas yang ada, bukan apa yang seharusnya. Dalam pandangan M. Umer Chapra, sebagaimana diresume oleh Royyan Ramdhani Djayusman, sekalipun ilmu ekonomi Islam akan tetap berkonsentrasi pada aspek alokasi dan distribusi sumber-sumber daya, seperti halnya pada ilmu ekonomi konvensional, namun tujuan utamanya harus merealisasikan maqashid. ${ }^{21}$

3. Ekonomi Islam adalah fiqh muamalah yang merupakan bagian dari ilmuilmu ke-Islaman dn berkembang pada awalnya dari tradisi keilmuan Islam. Pandangan ini dikemukakan oleh A. Qodri Azizy. Menurutnya dalam tradisi ilmu-ilmu keislaman ada disiplin ilmu yang disebut ilmu fiqh yang salah satu cabagnya disebut fiqh muamalah. Namun karena fiqh muamalah hanya dianggap identik dengan hukum perdagagan, fiqh muamalah menjadi terkungkung dengan hukum saja, padahal kalau dilihat topik bahasannya tidak berbeda jauh dengan bahasan ilmu ekonomi. Meskipun ciri fiqh itu sebenarnya berkembang, empiris dan realistik seperti karakteristik ilmu pada umumnya yang terbuka untuk berkembang, namun fiqh muamalah mandeg. Mengacu pada sejarah perkembangan pemakaian istilah fiqh yang semula tidak terkhususkan pada hokum, namun fiqh menjadi disiplin "hukum Islam". Tetapi meskipun fiqh identik dengan hukum, cakupannya ternyata lebih luas dan lebih banyak dalam pengertian etika agama bagi ilmu yang bersangkutan. Dilihat dari cakupannya yang sarat muatan etik agama, fiqh secara umum dapat diartikan dengan ilmu tentang perilaku manusia yang landasan utamanya adalah nash/wahyu." Atau lebih singkat "ilmu Islam tentang perilaku manusia." 22 Sehingga fiqh muamalah berarti ilmu Islam tentang perilaku manusia dalam berekonomi yang kini identik dengan ilmu ekonomi Islam.

\section{Pengembangan IImu Ekonomi Islam Berbasis Paradigma Unity of Science}

${ }^{21}$ Royyan Ramdhani Djayusman, Hakikat Ilmu Ekonomi Islam (Resume) Dr. M. Umer Chapra, http://ekonomikeadilan.wordpress.com/, diakses 26 April 2014.

22 A. Qodri Azizy, Membangun Pondasi Ekonomi Umat: Meneropong Prospek Berkembangnya Ekonomi Islam, Yogyakarta: Pustaka Pelajar, 2004, hlm. 175-184. 
Dari uraian sebelumnya nampak bahwa upaya menyemarakkan ilmu ekonomi Islam bukan untuk mendikotomikannya dengan ilmu ekonomi konvensional. Ilmu ekonomi yang diklaim positivistik dan bebas nilai dalam realitanya sulit terjadi. Sebagai contoh teori pasar bebas mengandung substansi nilai atau paham neoklasikal dan neoliberalisme. Menurut Sri-Edi Swasono, pengajaran ilmu ekonomi neoklsikal yang parsial tidak terlepas dari asumsiasumsi dasar atau mitos-mitos kapitalisme Smithian, yaitu bahwa: kebutuhan manusia tidak terbatas, sumber-sumber ekonomi relatif terbatas, pengejaran akan pemenuhan maksimal kebutuhan individual (utility maximization of selfinterest) relatif tak terbatas. Konsekuensinya muncul anggapan bahwa akhlak dasar manusia adalah bertarung dan saling berebut. Dari sini lahirlah gagasan tentang berlakunya perfect individual liberty dalam wujud semanat indiviu untuk bersaing dan membentukkan mekanisme free competition dalam kehidupan berekonomi. Isolasi diri ekonomi neoklasikal ini terbentuk tidak saja karena ideology liberalisme yang kuat sekall disandangnya, tetapi juga karena dalam perkembangannya telah mengabaikan kedudukan ilmu ekonomi sebagai ilmu moral. Karena itu Sri-Edi Swasono menegaskan perlunya koreksi, dekonstruksi, merombak, melakukan reformasi terhadap pemikiran-pemikiran ekonomi konservatif-konvensional yang menjerumuskan. ${ }^{23}$

Ketika ilmu ekonomi konvensinal pada awalnya mendikotomikan atau memisahkan antara ilmu dengan nilai, maka lmu ekonomi Islam sejak awal tidak mengenal dikotomi tersebut. Bahkan para ekonom konvensional akhirnya menyedari kekeliruan pemisahan antara ilmu ekonomi dengan nilai. Pemikiran-pemikiran ekonomi makin mengarah kepada sisi normatif sehingga dapat mengandung peran preskriptifnya untuk mencapai tujuan-tujuan imperatif, yaitu sebagai "ilmu amaliah" atau sebagai "political economics". Ilmu ekonomi "positif" dianggap tidak memecahkan masalah riil betapapun disusun berdasar fakta empirik. Bahkan ada kesimpulan bawa ilmu ekonomi akhirnya menjadi "mati" pada tataran "the death of economics". 24

${ }^{23}$ Sri-Edi Swasono, Ekspose Ekonomka: Mewaspadai Globalisme dan Pasar-Bebas, Yogyakarta: Pusat s'Tudi Ekonomi Pancasila-ugm, 2003, hlm. 2-6.

${ }^{24}$ Sri-Edi Swasono, Indonesia dan Doktrin Kesejabteraan Sosial - Dari Klasikal dan Neoklasikal Sampai ke The End of Laisseq-Faire, Jakarta: Perkumpulan PraKarsa, 2010, hlm. 4.

Volume V/Edisi 1/Mei 2014 
Dalam paradigma unity of science IAIN Walisongo, ilmu ekonomi Islam perlu dikembangkan bukan dalam rangka memperuncing perbedaan dengan ekonomi konvensional, bukan pula dalam rangka "menyaingi" kajian ekonomi konvensional yang sudah mapan. Namun pengembangan ekonomi Islam justru untuk berkomunikasi secara intensif dengan berbagai teori dalam ekonomi konvensional yang sudah ada. Karena suatu ilmu atau teori yang dikembangkan dengan perangkat metodologi ilmiah yang memadai hakekatnya juga berasal dari petunjuk Tuhan lewat ayat kauniyah sama halnya dengan ekonomi Islam yang dikembangkan dari ayat Qur'aniyah. Ketika kedunya tidak sinkron berarti ada masalah. Masing-masing bisa saling memperlengkapi kekurangan. Menurut A. Qodri Azizy, Ekonomi Islam harus sanggup mengisi kekosongan yang terjadi pada sistem ekonomi konvensional. Dalam hal ini, ekonomi Islam harus sanggup mewujudkan rahmatan lil 'alamin. ${ }^{25}$

Pengembagan kajian Ekonomi Islam dalam paradigma unit of science dapat dilakukan dengan strategi sebagai berikut:

1. Memperkuat ilmu ekonomi sebagai tool of analysis, meski dirumuskan oleh Barat namun jika teruji kesahihannya perlu dikuasai penuh oleh pengkaji ilmu ekonomi Islam. Dengan demikian, sebagai ilmu aqli yang juga karunia dari Tuhan, ilmu ekonomi positivistik perlu dikuasai. Karena dalam paradigm unty of science ilmu-ilmu smacam ini adalah pendalaman terhadap fenomena/ayat kauniyah, yang hakekatnya adalah juga ilmu Tuhan.

2. Ekonomi Islam dikembangkan dalam semangat spiritualisasi ilmu ekonomi. Ilmu ekonomi yang netral atau bebas nilai ternyata tidak ada. Bahkan ilmu ekonomi yang berasal dari Barat yang dianggap netral ternyata ditumpangi oleh faham neoklasik atau neoliberalis yang membawa dampak tidak sesuai dengan ekonomi kerakyatan. Pengkajian ilmu ekonomi Islam memberikan nilai Islam universal pada ilmu ekonomi positivistik, sehingga apapun nomenklaturnya, ilmu ekonomi harus mampu merealisasikan maqashid alsyari'ah di bidang ekonomi.

3. Ilmu ekonomi Islam dikembangkan dengan semangat humanisasi ilmu keIslaman. Ini bisa dikembangkan dengan konsep yang dibangun Qodri Azzy

${ }^{25}$ A. Qodri Azizy, Op.Cit., hlm. 195. 
yang berupaya menjadikan ilmu-ilmu ke-Islaman seperti fiqh muamalah memiliki kontribusi riil bagi kemaslahatan hidup. Pengkajian ekonomi Islam berparadigma unity of science tidak mentabukan pemikir-pemikir Islam yang lebih berorientasi pada kemaslahatan dari pada formalisme agama. Pengkajian ekonomi Islam yang demikian, bisa mengembangkan scara kritis akademis gagasan kreatif semisal gagasan Muhammad Syahrur, Fazlurrahman dan semisalnya yang tidak berbasis pada pengharaman bunga secara mutlak.

4. Pengembangan ilmu ekonomi Islam dalam kerangka revitalisasi budaya lokal merupakan wujud nyata tuntutan unity of science. Konsep 'urf dimaknai secara luas dan produktif sehingga berbagai transaksi atau aktiitas ekonomi yag berkembang di berbagai daerah dengan kekhasannya masingmasing perlu diapresiasi dan dikembangkan untuk kemaslahatan. Praktikpraktik ekonomi pedesaan dan daerah-daerah tertentu adalah khazanah yang dapat dipakai sebagai sarana pemberdayaan ekonomi masyarakat yang tepat.

\section{Kesimpulan}

Dengan paradigma unity of science yang dikembangkan IAIN Walisongo, keberadaan kajian ilmu ekonomi Islam menjadi fleksibel, dinamis dan produktif dalam memberikan nilai guna bagi kesejahteraan secara komprehensif (falah). Untuk mengoptimalkan hasilnya, pengembangan ekonomi Islam dilandasi dengan kerangka "ilmu alat" ekonomi yang memadai, sehingga personil civitas akademika bidang ekomi Islam memiliki tool of analyses yang handal. Dengan berbasis kerangka dasar ilmu ekonomi yang kuat dengan pemahaman unity of science yang memadai, pengembangan ilmu ekonomi Islam dapat secara optimal menggapai maqashid al-syari'ah yang hakiki bukan yang semu. Demikian juga basis unity of science ini dengan dipandu semangat spiritualisasi ilmu ekonomi, humanisasi fiqh muamalah/ilmu ekonomi Islam dan revitalisasi budaya ekonomi lokal, akan menjadikan pengkajian ilmu ekonomi Islam lebih memiliki daya guna komprehensif universal mewujudkan Islam sebagai rahmatan lil-‘alamin. 
Arab Pengembangan Kajian Ekonomi Islam

\section{DAFTAR PUSTAKA}

Kartanegara, Mulyadhi, Integrasi Ilmu: Sebuah Rekonstruksi Holistik, Bandung: Penerbit Arasy PT Mizan Pustaka, 2005.

Bisyri, M. Hasan, "Mengakhiri Dikhotomi Ilmu dalam Dunia Pendidikan", Forum Tarbiyah, Vol.7 No.9 Desember 2009.

Sholihan, "Epistemologi Pengembangan Ilmu dengan Paradigma Unity of Sciences/Wahdah Al-'Ulum (Ilmu Dakwah sebagai Model)", Disampaikan dalam Studium General Fakultas Dakwah dan Komunikasi IAIN Walisongo, Semarang, 3 Maret 2014.

Kamal, Muh. Amri Nur, "Filasafat Ilmu Pengetahuan", http://paradigmascience.blogspot.com/2011/05/ filsafat-ilmupengetahuan_15.html, diakses 25 April 2014.

Taufiq, Imam, "Komitmen Kebangsaan IAIN", Suara Merdeka, 7 April 2014.

Cauley, Troy J., Economics: Principles and Institutions, Pennsylvania: The Haddon Craftsmen, Inc., 1969.

Kahf, Monzer, The Islamic Economy, Analytical Economy of The Function of The Islamic Economic System, terj. Machnun Husein, "Ekonomi Islam (Telaah Analitik terhadap Fungsi Sistem Ekonomi Islam)", Yogyakarta: Pustaka Pelajar, 1995.

Muhammad, Prinsip-prinsip ekonomi Islam, Yogyakarta: Graha Ilmu, 2007, hlm. 1-14, dalam http://renoparay.blogspot.com/2013/, diakses 26 April 2014.

Taylor, Overton H., A History of Economic Thought, New York : McGraw-Hill Book Company, Inc., 1960

Skousen, Mark, The Making of Modern Economics The Lives and Ideas of the Great Thinkers, terj. Tri Wibowo Budi Santoso, "Sang Maestro Teori-teori Ekonomi Modern, Sejarah Pemikiran Ekonomi”, Jakarta : Prenada Media, 2005. 
Hasid, Zamruddin, “Reconstruction on Economic's Theory and Its Application : The Role of Islamic Bank", dalam : International Journal Ihya 'Ulum al-Din, Semarang : IAIN Walisongo, vol.7, no.1, Juli 2005.

Al-'Audhi, Rifa'at, "Murtakazat li Tadris al-Iqtishad al-Islami” dalam : Jad alHaqq 'Ali Jad al-Haqq, et.al, Abhats Nadwah Isham al-Fikr al-Islami fi alIqtishad al-Mu'ashir, Herndon : al-Ma'had al-'Alami li al-Fikr al-Islami, 1988.

Ash Shadr, M. Baqir, Ringkasan Iqtishaduna "Ekonomi Kita" Mąhab \& Doktrin Ekonomi Islam, Yogyakarta: RusyanFikr Institute, 2012.

Djayusman, Royyan Ramdhani, Hakikat Ilmu Ekonomi Islam (Resume) Dr. M. Umer Chapra, http://ekonomikeadilan.wordpress.com/, diakses 26 April 2014.

Azizy, A. Qodri, Membangun Pondasi Ekonomi Umat: Meneropong Prospek Berkembangnya Ekonomi Islam, Yogyakarta: Pustaka Pelajar, 2004..

Swasono, Sri-Edi, Ekspose Ekonomka: Mewaspadai Globalisme dan Pasar-Bebas, Yogyakarta: Pusat s'Tudi Ekonomi Pancasila-ugm, 2003.

Swasono, Sri-Edi, Indonesia dan Doktrin Kesejabteraan Sosial - Dari Klasikal dan Neoklasikal Sampai ke The End of Laissez-Faire, Jakarta: Perkumpulan PraKarsa, 2010. 
Arah Pengembangan Kajian Ekonomi Islam 